Article

\title{
The Role of Policy Makers and Institutions in the Energy Sector: The Case of Energy Infrastructure Governance in Nigeria
}

\author{
Norbert Edomah ${ }^{1,2, *}$, Chris Foulds ${ }^{1}$ and Aled Jones ${ }^{1}$ \\ 1 Global Sustainability Institute, Anglia Ruskin University, Cambridge CB1 1PT, UK; \\ chris.foulds@anglia.ac.uk (C.F.); aled.jones@anglia.ac.uk (A.J.) \\ 2 Information Systems Academy, Pan-Atlantic University, Lagos, Nigeria \\ * Correspondence: nedomah@pau.edu.ng; Tel.: +234-703-826-4790 \\ Academic Editor: Andrew Kusiak \\ Received: 3 May 2016; Accepted: 12 August 2016; Published: 22 August 2016
}

\begin{abstract}
This paper focuses on investigating the linkages and consequences of the policy decision process in the governance of energy infrastructure in Nigeria. It attempts to gain a better understanding of the role of policy makers and institutions in the provision of energy infrastructure in Nigeria. Using a combination of semi-structured interviews and documentary evidences from published literature, this study reveals three essential areas where the policy-making processes (and therefore policy makers) intervene in the provision of energy infrastructure. These are: (1) granting access to historical data; (2) regulations; and (3) permitting/issuance of licenses. This study also reveals three major unintended consequences of the policy decision processes and institutions in the governance of energy infrastructure provisions in Nigeria, which are: (1) government financing corruption in the energy sector; (2) economic delusion; and (3) uncontrolled growth in energy demand driven more by export and not local internal demand.
\end{abstract}

Keywords: energy economics; energy governance; public policy; developing countries; Nigeria; sustainable energy

\section{Introduction}

Energy is important today, and will still remain important going into the future [1]. Energy is still what binds a lot of communities and nations, particularly through country level energy strategies $[2,3]$. A great deal of emphasis, in many parts of the world, still remains in securing energy supply $[4,5]$. For some countries, it is about reducing dependence on imports and looking for new energy sources, routes, and suppliers that make a better economic sense [6]. For others, it is about having a strong economy, while minimizing any adverse effect on the climate, driving job creation, and having a gradual transformation of the entire transport system from predominantly fossil fuel based, among other sectors $[7,8]$. For some countries, the focus is on having a fully integrated internal energy market, without regulatory or technical barriers, in order to freely compete and provide the best energy prices that can drive growth in the economy [9].

Over time, the increasing role of governments and public institutions in many countries and regions has been felt through more regulation of the activities in the energy industry $[10,11]$. This increased regulation of the energy industry poses some questions: How does the policy decision process affect the governance of energy infrastructure provision? How have historical decisions affected energy infrastructure provision? What are the linkages between the policy decision process and the governance of energy infrastructure? What are the (intended and unintended) consequences of the policy decision process? Answering some of these questions is important in better understanding 
the consequences of the policy decision process and how to mitigate the adverse and unintended effects of such decisions. This is needed because knowledge of the effects of the policy decision and governance process helps in ensuring that decisions made have limited unintended consequences [12].

This study is important for Nigeria because the world is dramatically changing the options for technology and is fundamentally reassessing its energy resource base [13]. It is a world where even the demand and supply fundamentals are changing, particularly on the demand side, as new technologies allow us to use energy more efficiently and enable new energy services which were not technically feasible in the past (e.g., electric vehicles and smart grids) [14]. It is a world that also has to manage a new set of systemic issues; such as if we have a system of supply that is built on intermittent sources, what sort of storage is needed? If we want to manage energy intelligently through this century (including security of supply, affordability, climate change, air pollution, energy access, etc.), what is the actual knowledge needed to provide a sound foundation for intelligent decision making [15]? How do we control these sorts of system integration issues? Addressing these issues within the Nigerian context requires both energy and policy governance structures.

Using Nigeria as a case study, this paper aims to investigate the linkages and consequences of the policy decision processes and institutions in the governance of energy infrastructure provision.

In exploring the research question, this paper starts with a background (Section 2), and methodological considerations (Section 3). The paper highlights the linkages between policy making and institutions in the governance of energy infrastructure provision, and concludes by highlighting the three major unintended consequences of the policy decision processes and institutions (Section 4).

\section{Research Context}

The investigation of energy infrastructure governance in Nigeria was prompted by the need for more research and understanding into the role of policy makers in energy infrastructure decisions. Over the next years and decades, the global energy infrastructure is set to transform, incorporating new technology, as well as addressing new challenges, such as climate change. Fast growing, resource rich developing countries offer an interesting case to explore these dynamics in a specific context. Investigating the influences underlying past changes in Nigeria's energy supply infrastructure with a view to understanding the interconnections and policy making influences on energy supply infrastructure is therefore the focus of this paper.

Figure 1 presents the Nigerian energy flow, which shows the linkages between primary energy resources and various end use applications in Nigeria. The figure shows petroleum (crude oil) as the most extracted energy resource [16]. However, much of it is exported. The second most produced form of energy source is biomass, which is also the most commonly used, providing energy services in majority of homes particularly in rural areas. Natural gas is used more for electricity generation (both for industry and large power plants). Why are wind, solar, geothermal, and nuclear sources not deployed? What policy contexts or energy market structure influenced the use and misuse of various energy resources? What policy contexts influenced the kind of energy infrastructure we ended up with? Answers to these questions can be better understood by having a better appreciation of the historical contexts of the various energy (infrastructure) sources.

Investigating the historical relationship between energy infrastructure provisions and policy making enables a better understanding and appreciation of the factors that have influenced policy making in the past, thus, providing the base knowledge required for future projection of possible factors that might influence energy infrastructure provisions and governance in the future. Section 2.1 delves into the Nigerian energy transitions, which provides a background to the study that forms the central focus of this paper. 


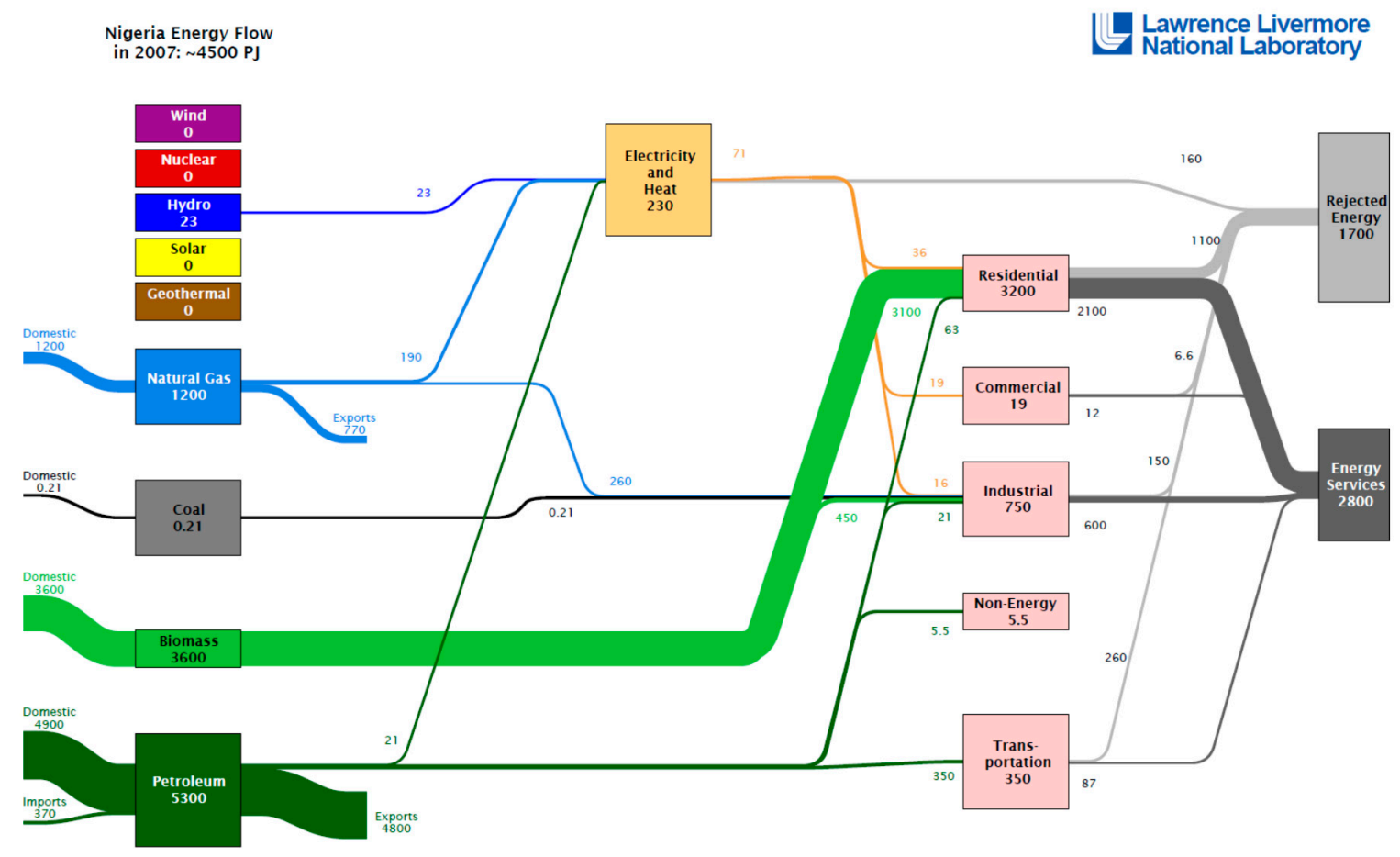

Figure 1. The Nigerian energy flow [17] (p. 90).

\subsection{The Evolution of Energy Systems in Nigeria}

Changes and evolution in energy systems involves "long term structural changes in energy systems" [18] (p. 2). Energy is critical for wellbeing and economic development as there is great value in having access to energy [19]. However, there is a basic tension between energy production, consumption, and its corresponding effects (such as pollution) that threaten our wellbeing [20]. Over the years, energy security has become an issue of great importance [21]. It is considered important in international relations, global safety, and humanity's survival. The renewed focus on energy security is partly driven by exceedingly tight oil market and fluctuating oil prices [22]. Threats in the forms of terrorism, instability in some oil exporting countries, geopolitical rivalries, and the fundamental needs of countries for energy to power their economies constitutes some factors that threaten security of supply [23]. Energy security no longer stands by itself, as it is now entrenched in many other interconnected local, regional, and global issues, as well as in the larger relationships and interactions among nations [24].

There are not many studies of the evolution of energy systems in Nigeria. However, in a study, which focused on the evolution of energy infrastructure provisions (1800-2015), the authors presented the history of energy extraction and use in Nigeria by breaking it into different eras of energy use [25]. The study was conducted based on the trimetric parameters of: energy demand and use; technology driving demand (and eventual supply) of energy; and the primary energy resources used in satisfying the demand for energy, within each era of energy use. It also focused on the role of institutions, within each era, in effecting changes in energy systems and use. The study reveals that, with respect to energy supply infrastructure, there is a complex connection between resources, trade, institutions, and political structures [26]. The study also revealed that this same evolution was supported by, and contributed to the creation of, several decision-making institutions within each era of energy use, as well as the policy direction of the government [26]. It stressed the need for sustained public investment and leadership by public government institutions in order to ensure the adequate provision of the needed energy infrastructure. However, there is need for increased partnership between public institutions, industry, and private investors in order to improve access to energy and foster new clean energy technology development and deployment [27]. Governments, through public institutions, need 
to provide economic incentives to increase energy infrastructure provision through promulgation of policies to aid private investment [28-30]. Governance plays a vital role in energy supply security, which, in turn affects, other sectors that rely on energy (e.g., residential, transportation, and industry sectors) [31].

It is these aforementioned studies that have provided the background for the authors to explore energy infrastructure governance in Nigeria by focusing on the linkages and consequences of the policy decision processes and institutions. This paper aims to answer the question: "What are the linkages and consequences of the policy decision processes and institutions in the governance of energy infrastructure provision?" While considering energy in this study, what is implied is the broad spectrum of energy sources, which includes coal, natural gas, crude oil, and renewables. There are multiple challenges that comes with dealing with energy, which requires science-based, comprehensive, integrated, and policy-relevant analysis of options and issues related to: Resources and technology options with respect to demand and supply; energy and sustainability challenges; systems issues and scenarios; and policy options [32]. It is important to address the political issues associated with energy while seeking new ways of addressing energy policies that recognizes multiple benefits, looking at policies that addresses the needs we have across different energy areas like energy security, air pollution, climate change, and other interconnected issues [33]. However, what exactly constitutes the process of policy formulation?

\subsection{The Policy Cycle}

There are six important stages that contribute to policy formulation, as highlighted in Figure $2[34,35]$. These six stages that contribute to policy cycle are:

1. Awareness stage-The emphasis is on gathering information about the key that may necessitate the need and development of a policy (e.g., energy access, carbon emission). The potential barriers and opportunities are identified, collected, and analyzed at this stage.

2. Problem definition stage-The implications of potential barriers and problems are identified at this stage, e.g., the problems relating to energy infrastructure provision.

3. Identification of options stage-The possible consequences of the potential policy options are assessed. An example could be the consequences of decentralizing electrical power generation and its impact at the socio-economic, environmental, and technical levels.

4. Policy selection stage-A choice is made regarding the preferred policy, which builds on the previous stages' understanding of the associated problems and their implications. An example could be choosing an energy generation decentralization policy that addresses the problem of energy access, while improving energy security and reducing vulnerability.

5. Policy implementation stage-There is a translation of policy into action. This essentially means the adoption of a particular policy after all the necessary deliberations by concerned stakeholders.

6. Policy evaluation stage-Evaluation, monitoring, and tracking of the chosen policy is done in order to ascertain the progress. The evaluation, monitoring and tracking process also helps in measuring the awareness level. Constant evaluation and monitoring of energy access helps in determining the number of persons that have access to energy after a given period, and also to help in ascertaining what amount of energy infrastructure is required to bridge the identified gap in energy infrastructure deficit to address energy access issues. 


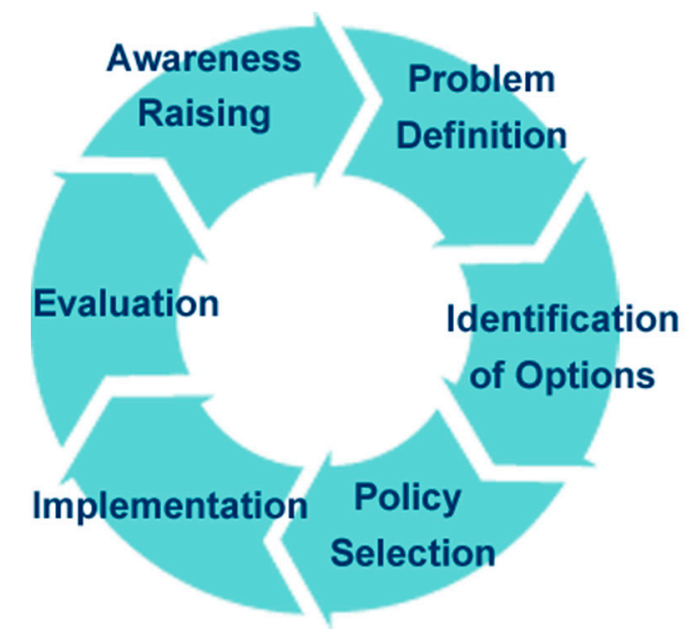

Figure 2. The various stages of the policy cycle [28].

The policy cycle has been introduced in this section as a template for analyzing a good policy formulation process. In other words, we will be analyzing how closely this cycle is followed in the context of the provision of energy infrastructure in Nigeria.

\section{Materials and Methods}

In investigating the linkages and consequences of the policy decision processes and institutions [10] within the Nigerian context, a mixed method [36] research design was used founded on the research philosophy of critical realism [37]. A combination of documentary literature search and semi-structured interviews were used in executing this study. Documentary data from research outputs in published literatures and official statistics of private and public, local and international, institutions were used. Semi-structured interviews $[38,39]$ were used to obtain qualitative data from policy makers who have been involved in the historical and current decision making process in Nigeria. During the interview, the focus was to find out about the historical energy policy governance structure, with a view to understanding the intended and unintended consequences of the policy decision process. The focus on the unintended consequences was prompted by the need to understand why policies might fail. The interviewees were comprised of politicians and energy experts from private and public institutions with an average professional experience (either in policy making, as is the case of the politicians, or in energy infrastructure supply, operations, or maintenance, as is the case of the energy experts) of 20 years. Table 1 shows a list of some of the interviewees, their background, and the dates of the interview.

Interview notes were taken during the interviews rather than taking audio recording. The use of audio recording was avoided due to the high profile nature of the interviewees in order to encourage them to speak freely and to be more open [40]. This was informed by the cultural context of Nigeria where high profile individuals feel uncomfortable answering sensitive questions that is being audio recorded. This method also fosters anonymity.

The interview notes were coded using pen and paper in order to discover recurring codes, categories and themes [41]. The themes, together with some evidence gathered from published literature, forms part of the research findings. 
Table 1. Some interviewees and their background/expertise.

\begin{tabular}{|c|c|c|}
\hline Interviewees & Background/Expertise & Date of Interview \\
\hline A & $\begin{array}{l}\text { An experienced socio-political expert and economist. He was once a } \\
\text { senior special adviser to the president on policy implementation. } \\
\text { He has been working and consulting for the government for over } \\
20 \text { years. }\end{array}$ & 13 June 2015 \\
\hline B & $\begin{array}{l}\text { A senior politician with over } 15 \text { years' experience in the art of policy } \\
\text { making. He was once a special assistant to an executive governor. } \\
\text { He later moved to the Federal House of Representatives as a } \\
\text { lawmaker where he chaired the house committee on treatise and } \\
\text { policy for several years. }\end{array}$ & 20 June 2015 \\
\hline $\mathrm{C}$ & $\begin{array}{l}\text { A politician with over } 20 \text { years' experience in politics. He was a } \\
\text { speaker of a state house of assembly for several years where he } \\
\text { chaired several policy sessions at the state house of assembly. }\end{array}$ & 18 July 2015 \\
\hline $\mathrm{D}$ & $\begin{array}{l}\text { A senior technical expert in energy with over } 20 \text { years industry } \\
\text { experience. He spent a large part of his working career with the } \\
\text { Transmission Company of Nigeria (TCN) where he had technical } \\
\text { responsibility for the smooth operation and maintenance of a } \\
\text { section of the country's electricity grid network. }\end{array}$ & 15 August 2015 \\
\hline $\mathrm{E}$ & $\begin{array}{l}\text { A senior energy expert with more than } 30 \text { years' experience in the } \\
\text { electrical power industry. He had responsibility for the general } \\
\text { management and operations of one of the regions of the } \\
\text { Transmission Company of Nigeria (TCN). Prior to that, he worked } \\
\text { with the then National Electric Power Authority (NEPA) from early } \\
\text { 1980s, and later the Power Holding Company of Nigeria where he } \\
\text { worked at senior levels. He saw a large part of the policy and } \\
\text { technical transitions of the Nigerian electrical power sector during } \\
\text { his working career. }\end{array}$ & 24 August 2015 \\
\hline $\mathrm{F}$ & $\begin{array}{l}\text { An engineer with several years' experience working in the energy } \\
\text { industry. He worked in Nigeria's biggest thermal power station for } \\
\text { several years where he handled several roles. }\end{array}$ & 8 September 2015 \\
\hline G & $\begin{array}{l}\text { A communications expert with several years' experience in the } \\
\text { energy industry. He was Head of Corporate Communications for } \\
\text { one of Nigeria's biggest electrical distribution company for } \\
\text { several years. }\end{array}$ & 20 September 2015 \\
\hline $\mathrm{H}$ & $\begin{array}{l}\text { An engineer with several years' experience in energy technology } \\
\text { industry. He worked with some top Original Equipment } \\
\text { Manufacturers involved in manufacturing and sales of power } \\
\text { turbines and electrical network solutions. He has spent a large part } \\
\text { of his working career in technology sales and marketing, interfacing } \\
\text { with many of the end users and several stakeholders in the Nigerian } \\
\text { energy sector. }\end{array}$ & 30 September 2015 \\
\hline
\end{tabular}

\section{Findings}

This section presents two broad findings, based on the interviews and documentary analysis, of this study. Section 4.1 presents the linkages between the policy-making processes and institutions in the governance of energy supply infrastructure, while Section 4.2 presents the unintended consequences of the policy decision processes and institutions in the governance of energy infrastructure provision.

\subsection{Linkages between Policy Making Processes and Institutions in the Governance of Energy Supply Infrastructure}

In investigating the linkages between energy infrastructure provision and policy making within the Nigerian context, the interviews conducted revealed three major themes, which are viewed as the lenses through which those in the policy space exert some sort of influence on the affairs of the Nigerian energy industry [42]. These are: 
- Issuance of licenses/permitting

- Regulations

- Granting access

Permitting involves the granting of an official permission or authoritative certificate for an entity to perform certain actions [43]. Energy regulations entail the rules governing the extraction, production, sale, and use of energy [44]. Granting access to historical data on the sector's activities can help investors shape their business expectations and ascertain some of the embedded business risks, which might still be unclear. However, how important are permits and regulations in the energy industry and energy market [45]?

Within the Nigerian context permitting and licensing provides the entry points for participation in the energy industry. The federal ministry of petroleum resources oversees the affairs of the Nigerian oil and gas industry through the Department for Petroleum Resources (DPR). The DPR also oversees the affairs of the Nigerian Nuclear Regulatory Authority, responsible for the development and regulation of nuclear power in Nigeria. DPR has the statutory function of processing and granting approvals, licenses and permits across the entire oil and gas value chain. This ranges from exploration and production permits to retailing activities of oil and gas by-products. In addition to granting permits, DPR has responsibility for compliance to regulations, guidelines, and petroleum laws within the entire oil and gas spectrum in Nigeria.

Indeed there is need for regulation and competition in energy markets which assures both the freedom of enterprise and the freedom of choice of the consumers [46]. It grants the benefits of efficiency that comes from the choice of available options, and provides an ideal environment for promoting innovation [45]. It is argued that there are no fair competitions in a market where there are no rules, which is why regulations are promulgated to govern the affairs of a sector or market. Since competition does not happen by itself, competition laws and policies are promulgated in order to ensure that entities do not develop unfair market power, which restricts competition [47]. Laws and institutions are set up not only to prevent cases of market power, but also to punish the abuse of such when it arises [48].

Additionally the Nigerian electricity and gas market, in generic terms, has been traditionally designed to be monopolistic in nature [49]. This has been supported by the argument that it is better for a single entity to take responsibility for the entire value chain of the energy supply and energy infrastructure system so as to ensure the proper handling of technical, efficiency, and interconnection issues. This is one of the main contributors to the natural monopoly in the Nigerian energy (and particularly electricity) market that was experienced for a long time, until 2005, when the new roadmap on electricity reforms paved the way for future private sector participation.

It has been argued that in the electricity supply industry, it is possible to maintain a unique network with several companies in the value chain of electricity and gas generation, extraction, production, and sales [49]. This is only possible however, for those companies, which already have access to essential facilities in the network, as defined under certain conditions that are detailed in the regulations.

Taking a page from the experiences of some developed economies in different parts of the world, regulatory institutions governing the different parts of the energy sector have either been transformed, or new ones set up [50]. These institutions are generally considered as independent with respect to the regulated companies, and have to be protected from excessive influence of the regulated companies on their regulator [51]. However, there might be cases where the government owns majority shares of large energy companies, as is the case of Nigeria. What should happen in principle is that the regulator should be independent of the government, however, in practical terms, it is quite difficult not to have some level of influence [52]. Table 2 presents a summary of the areas of policy/regulatory interventions in primary energy resource extraction and development within the Nigerian context, as obtained from the interviews conducted, and the documentary search. 
Table 2. The linkages/areas of policy and regulatory interventions in the extraction and development of energy resource infrastructure.

\begin{tabular}{|c|c|c|c|c|c|}
\hline & \multicolumn{5}{|c|}{ Energy Resource (Extraction) and Infrastructure Development } \\
\hline & & Oil and Gas & Coal & Gas and Electricity & Nuclear \\
\hline \multirow{3}{*}{$\begin{array}{c}\text { Areas of policy and } \\
\text { regulatory } \\
\text { interventions }\end{array}$} & $\begin{array}{l}\text { Issuance of } \\
\text { licenses }\end{array}$ & $\begin{array}{l}\text { Licensing participants involved in } \\
\text { natural gas and crude oil } \\
\text { exploration and production }\end{array}$ & $\begin{array}{l}\text { Issuing licenses for coal } \\
\text { exploration } \\
\text { and extraction. }\end{array}$ & $\begin{array}{l}\text { Licensing of participants and players in the } \\
\text { electricity and gas market. }\end{array}$ & $\begin{array}{l}\text { Providing licenses and } \\
\text { permits to } \\
\text { market players. }\end{array}$ \\
\hline & Regulations & $\begin{array}{l}\text { Regulations with respect to: } \\
\text { New oil and gas field development } \\
\text { and pipeline activities } \\
\text { Environmental aspects of oil and } \\
\text { gas extraction, production } \\
\text { and decommissioning. }\end{array}$ & $\begin{array}{l}\text { Managing environmental } \\
\text { effects of historical mining } \\
\text { activities, such as } \\
\text { contaminated water } \\
\text { from coalmines. }\end{array}$ & $\begin{array}{l}\text { Providing the required framework for } \\
\text { regulation of the electricity and gas market. } \\
\text { Appointing members of the various national } \\
\text { public institutions that set the strategy for the } \\
\text { development and provision of various types of } \\
\text { infrastructure, such as: Federal Ministry of } \\
\text { Power; National Electricity Regulatory } \\
\text { Commission; Nigerian National Petroleum } \\
\text { Corporation; Standards Organization of Nigeria; } \\
\text { and other relevant stakeholders. }\end{array}$ & $\begin{array}{l}\text { Providing regulatory } \\
\text { framework and } \\
\text { regulations for licensing } \\
\text { and permitting. }\end{array}$ \\
\hline & Granting Access & $\begin{array}{l}\text { Granting access to oil and gas } \\
\text { exploration and production data. }\end{array}$ & $\begin{array}{l}\text { Access to mining } \\
\text { information/data. }\end{array}$ & $\begin{array}{l}\text { Access to historical and resource data, such as: } \\
\text { quantities and location of gas reserves, water } \\
\text { resources, etc. }\end{array}$ & $\begin{array}{l}\text { Access to natural } \\
\text { resource data such as } \\
\text { location and quantity of } \\
\text { uranium reserves. }\end{array}$ \\
\hline
\end{tabular}




\subsection{Governing Energy Supply Infrastructure: The Unintended Consequences of Policy Decision Processes and Institutions}

The governance of energy infrastructure change involves different stakeholders (energy users, industry, residential, energy investors, policy makers, etc.) who are important actors in influencing the kind of decisions made and the energy infrastructure we subsequently end up with [53]. However, the dynamics and complexities governing energy infrastructure provisions leads to many stakeholders employing different lobbying mechanisms to make their positions known, prioritized, and then adopted [54]. Satisfying the interests of different stakeholders in the governance of energy infrastructure provisions necessarily leads to some unintended consequences [55]. We find three major unintended consequences of the policy decision processes and institutions in the governance of energy infrastructure provision in Nigeria are:

- Government (unintentionally) financing corruption in the energy sector

- Economic delusion

- Energy demands driven more by export needs rather than local consumption.

The following sub-sections further delve into the details of the aforementioned unintended consequences.

\subsubsection{Increased Opportunities for, and Incidence of, Corruption in Over-Centralized Governance}

Prior to independence in 1960, Nigeria existed as regions with regional governments. Policy decisions were taken at regional, as well as national levels. The decision-making process at that point was decentralized. This meant that the various regional governments could draw up and implement policies on different aspects of life in society, including resource extraction and production, while they made some contribution to the central government. The regional system of government created some sort of healthy competition among the regions, which aided the discovery and development of (mineral and energy) resources in the different regions. However, with the advent of crude oil and military rule in the 1970s, the governance structure was upturned by the military. The control and governance of (mineral, energy, and other) resources, including strategic planning, were centralized and controlled by the central government. This means that all the prospects and challenges of the different regions were now centralized, that the central government decides who should have what, and that many decisions (including social and economic) were heavily politicized. Indeed, this has also affected the way in which energy infrastructure is governed in Nigeria. From the findings of the interviews, it is argued that the military upturned things to their favor in order to have full control of the country's resources (particularly crude oil).

Nigeria's centralized system of decision making was driven by the quest for political power, while political power was driven by corruption as those in the political space were greatly enriched by the system.

(Extract from interview notes)

The centralized system of decision-making has become deeply embedded in the Nigerian political culture. Despite the apparent collapse of military rule, there is still a well-entrenched centralized decision-making culture within the democratic setting [56]. This is because many political players within the current democratic setting were either once in the military, or served under the military rule where this culture has been historically entrenched. However, how did corruption come into the scene [57]?

Opportunities for corruption emerged from certain governance and institutional structures and practices, rather than being intentionally designed [58]. Before the privatization and decentralization of the electrical power sector, the government had been responsible for both provision of new energy supply infrastructure, as well as the maintenance of existing energy infrastructure. The Nigerian 
Electric Power Authority (NEPA), which later metamorphosed to the Power Holding Company of Nigeria (PHCN), an institution of the federal government of Nigeria, had the responsibility of managing every aspect of the electrical power network from the generation plants, to transmission, and distribution network infrastructure [59].

Like every other government institution, NEPA prepares a plan for overhaul, upgrade and maintenance of some targeted aspects of the electrical network infrastructure each year [60]. However, the culture has been that, for example, if NEPA requires $\$ 3$ million for a major overhaul of a power plant, the government may decide to release $\$ 1.5$ million for the project, and inform the public that funds have been released for the required overhauls, as such, there should be improved electricity supply.

\section{... when the NEPA brings to the fore (mostly in writing) that the released funds cannot complete an overhaul, the typical response is "that's what we have; you have to use it as that is what our budget can accommodate."}

(Extract from interview notes)

As such, the NEPA is left with the option of having a makeshift maintenance arrangement (which cost much less than the funds released) rather than have a complete overhaul. This can result in more funds in the possession of those responsible to do the supposed 'overhaul', which ends up as a 'routine maintenance service'; and the extra funds, many a times, do not manage to find their way back to the government treasury [61]. This is one of the reasons why fighting corruption in the Nigerian energy sector still proves to be very difficult $[61,62]$.

\subsubsection{Economic Delusion}

A major unintended consequence of the policy decision system in this sector is economic delusion [63]. Economic delusion is simply the falsity or deceit that the economy is thriving and waxing strong whereas the reverse is the case [64]. It is believed that Nigeria saw an economic boom in the 1970s, particularly as it relates to industrialization and investment in agricultural processing plants. However, this was not the case in reality; Nigeria was de-industrializing during that period, but what was responsible for this?

Economic delusion was caused by the false perception of economic growth. In the 1970s, Nigeria started experiencing growth in the oil and gas production and export, while there was a simultaneous decline in manufacturing activities. The focus on developing the oil industry due to its huge prospects for increased income led to less attention being given to the manufacturing and industrial sectors. This occurred through non-judicious implementation of established energy policies targeted to aid industrialization. Thus, growth of established industries was restricted by limited available (electrical) energy supplies [59].

From the late 1920s, future projections of energy demand were made with the aim of ensuring that energy infrastructure was provided to aid future industrialization prospects, and in particular, to support the growth of the agro-allied and food processing industries [65]. These future projections led to the establishment of the then Nigerian Government Electricity Undertaking (NGEU). The NGEU was set up in 1946 to make a concrete plan of increasing electricity supply infrastructure to meet future demand of electricity for both residential and industrial use. This led to the 10-year plan covering a period of 1946-1956, which aimed at increasing the electricity supply by around $200 \%$. This plan led to massive industrialization from the 1950s, as this was the period that many investors in the agro-allied and food processing sector established a presence and set up their factories in Nigeria. Thus, by 1971, there were more than 2000 industries in Nigeria involved in food processing/agro-allied manufacturing [66].

In the 1970s, the actual electricity infrastructure provision was much less than the previously estimated projections [59]. This led to a situation where the growth of many of the industries was limited by the amount of available electrical energy [67]. Expansion and growth became impossible for many of the manufacturing industries while they were left with the option of growing at the pace with 
which electrical energy infrastructure was provided. Thus, the inadequate provision and supply of electrical energy infrastructure limited the growth of the manufacturing sector, which then worsened, through de-industrialization, as all future growth in industrialization activities was halted by the non-provision of electrical supply infrastructure [19]. It is a popular belief that the 1970s was the real industrial economic boom period for Nigeria; however, it was actually the period of industrial decline.

\subsubsection{Energy Demand Driven More by Export Need and Not Local Consumption}

The interviews revealed that it was the initial provision of energy supply infrastructure that led to the uncontrolled growth in demand for energy. From Figure 1 (showing the Nigerian energy flow), the following are quite obvious-which seem to conform to some of the findings of the interviews:

1. There is a large demand for petroleum (crude oil) and natural gas. However, a large part of the extracted crude oil and natural gas are exported. This signifies that the energy supply infrastructure provided in Nigeria was not meant to satisfy only the local demand, but also to meet the demands of the international market.

2. The residential sector is the largest consumer of energy resources in Nigeria with a large part of these resources coming from traditional biomass used more for energy services within the home. A large part of this energy, however, is being wasted through emissions and inefficient equipment and appliances.

3. Hydropower, natural gas, and crude oil (petroleum) are the three dominant resources used for electricity generation, with a potential for natural gas growing geometrically due to the policy direction of the Nigerian government to use more natural gas for electricity generation.

4. The industrial and commercial sectors combined, use far less energy resources in comparison with the residential sector.

\section{Discussion}

There is a traditional notion of institutional independence, which most likely underestimates policy makers' capacity to (in)directly shape energy policy. This traditional notion tends to overlook why lawmakers might want to shape energy policy. It is important, when analyzing the works of international governmental organizations, to not only to look at rational calculations, but also the pre-existing values and norms that informs the workings of those institutions. It is also important to understand the mind-set of those who have to design those institutional workings. An approach that takes into consideration history, context, and values are important in creating legitimacy and efficiency in the internal workings of institutions.

Under ideal situations, the policy cycle described in Section 2.2 provides a template for the effective formulation of policies. However, this study reveals that the policy cycle is not an actual cycle in practical terms. This is what results in some unintended consequences experienced as a result of not maintaining the policy cycle model. Figure 3 shows what the actual cycle looks like. It is not an actual cycle, as most of the individual stages are handled independently of the others. This is what results in unintended consequences, which often can be traced to lack of interaction and stakeholder engagement in the policy development process. 


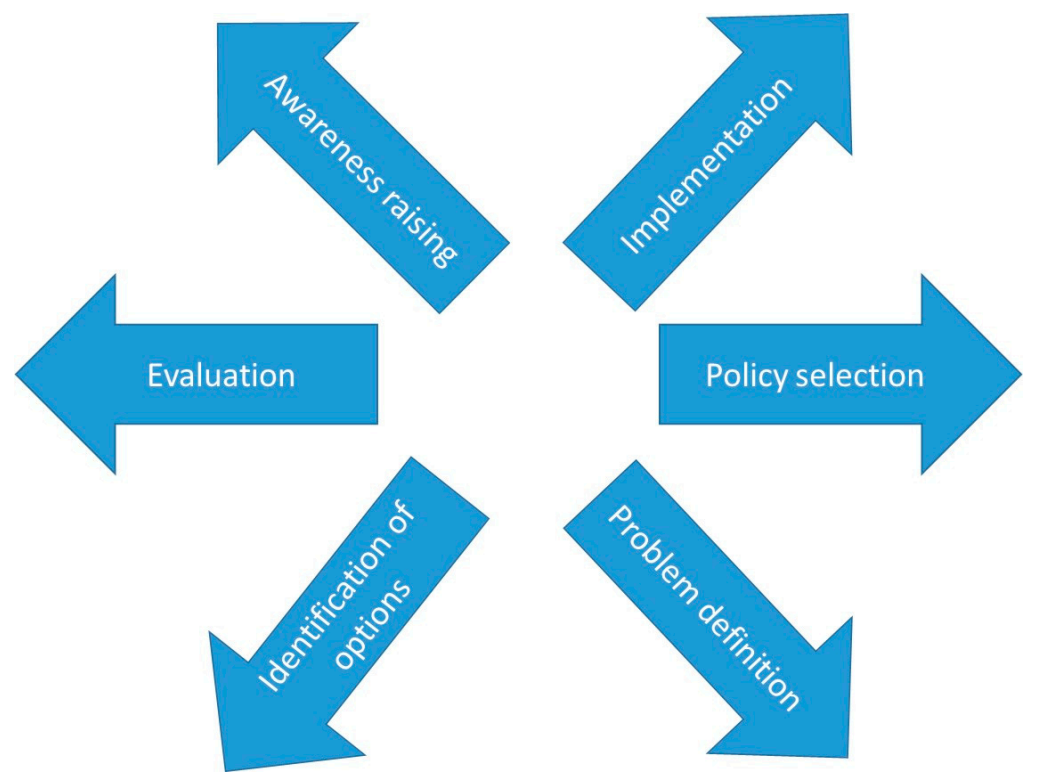

Figure 3. The actual policy cycle stages, which is not a cycle.

\section{Conclusions}

This paper aims at investigating the linkages and consequences of policy-making processes and institutions, and energy infrastructure provisions in the context of Nigeria. The study reveals that the policy making process interacts with energy infrastructure provisions through: Permitting/issuance of licenses; regulations; and granting access (particularly to historical data). It also reveals the unintended consequences of the policy making processes and institutions as: increased opportunities for corruption in over-centralized governance systems; economic delusion; and energy demand driven more by export need, and not by local consumption.

Following the findings of this paper, it is crucial for the Nigerian government to define the energy infrastructure and governance nexus in order to limit the effects of unintended consequences. It is also crucial that the governance and provision of energy supply infrastructure be decentralized and polycentric. This will enable different tiers of government to make decisions and implement their energy infrastructure choices.

The paper reinforces the need for policy makers and regulatory institutions to stay focused and concentrate on the task that is their mission. Policy makers have to be accountable to government by providing a clear description of the results of their activities, which should be consistent with the directives that set up such institutions in order to limit the cases of unintended consequences. Regulations are meant to be built to create a stable environment to facilitate investment and proper management of the companies that are players in the energy market.

The issues of unintended consequences in energy policy governance pose some questions such as: what policy decision models can be adopted in the governance of energy infrastructure provision that produces the least unintended consequences? How can energy policy decisions in developing countries be improved within the context of their geography? These are gaps that can be filled by further research.

Acknowledgments: Special thanks to NREL for permission to use the Nigerian energy flow chart.

Author Contributions: Norbert Edomah conceived and designed the research study as part of his Ph.D. research. Chris Foulds and Aled Jones provided inputs during the analysis and they also supervised the research. Norbert Edomah wrote the paper.

Conflicts of Interest: The authors declare no conflict of interest. 


\section{References}

1. Strbac, G.; Konstantelos, I.; Aunedi, M.; Pollitt, M.; Green, R. Delivering Future-Proof Energy Infrastructure; Report for National Infrastructure Commission; University of Cambridge Energy Policy Research Group: Cambridge, UK, 2016.

2. Konadu, D.D.; Mourão, Z.S.; Allwood, J.M.; Richards, K.S.; Kopec, G.; McMahon, R.; Fenner, R. Land use implications of future energy system trajectories-The case of the UK 2050 Carbon Plan. Energy Policy 2015, 86, 328-337. [CrossRef]

3. Hall, S.; Foxon, T.J.; Bolton, R. Financing the civic energy sector: How financial institutions affect ownership models in Germany and the United Kingdom. Energy Res. Soc. Sci. 2016, 12, 5-15. [CrossRef]

4. Leiby, P.N. Estimating the Energy Security Benefits of Reduced U.S. Oil Imports; Oak Ridge National Laboratory: Oak Ridge, TN, USA, 2007.

5. International Energy Agency (IEA). Energy Technology Perspectives 2012 Pathways to a Clean Energy System; International Energy Agency: Wien, Austria, 2012.

6. Greenpeace International. Energiewende: The energy transformation in Germany. In Proceedings of the Background Briefing for the IPCC WG3 Report, Berlin, Germany, 7-11 April 2014; pp. 1-4.

7. Dineen, D.; Howley, M.; Holland, M. Energy in Transport-2014 Report; Energy Policy Statistical Support Unit, Sustainable Energy Authority of Ireland: Dublin, Ireland, 2014.

8. International Energy Agency (IEA). Energy and Climate Change; World Energy Outlook Special Report; International Energy Agency: Wien, Austria, 2015.

9. Navarro, A.M.; Sambodo, M.T. The Pathway to ASEAN Energy Market Integration; Philippine Institute for Development Studies, Discussion Paper Series; Philippine Institute for Development Studies: Quezon, Philippines, 2013.

10. Scott, C.A.; Pierce, S.A.; Pasqualetti, M.J.; Jones, A.L.; Montz, B.E.; Hoover, J.H. Policy and institutional dimensions of the water-energy nexus. Energy Policy 2011, 39, 6622-6630. [CrossRef]

11. U.S. Energy Information Administration (EIA). Annual Energy Outlook 2014 Early Release-Overview; U.S. Energy Information Administration: Washington, DC, USA, 2014; pp. 1-13.

12. Kander, A. Economic Growth, Energy Consumption and $\mathrm{CO}_{2}$ Emissions in Sweden 1800-2000; Lund Studies in Economic History; Lund University: Lund, Sweden, 2000.

13. World Energy Council. World Energy Resources 2013 Survey; World Energy Council: London, UK, $2013 ;$ p. 468.

14. Braun, F.G. Technological Change and Energy-An Empirical Assessment of Innovation and Adoption; School of Economics and Management, Technische Universitat Berlin: Berlin, Germany, 2011; pp. 1-157.

15. Doukas, H.; Patlitzianas, K.D.; Kagiannas, A.G.; Psarras, J. Energy policy making: An old concept or a modern challenge? Energy Sources B Econ. Plan. Policy 2008, 3, 362-371. [CrossRef]

16. African Development Bank, African Union. Oil and Gas in Africa; Oxford University Press: Oxford, UK, 2009; pp. 1-233.

17. Smith, C.; Belles, R.; Simon, A.J. Estimated International Energy Flows; Lawrence Livermore National Laboratory: Livermore, CA, USA, 2011.

18. Davidsson, S. Global Energy Transitions: A Comparative Analysis of Key Countries and Implications for the International Energy Debate; World Energy Council: London, UK, 2014; pp. 1-26.

19. Stern, D.I. The Role of Energy in Economic Growth: The Case of Croatia; SSRN eLibrary: Rijeka, Croatia, 2010; Volume 28, pp. 54-56.

20. Van de Ven, D.J.; Fouquet, R. Historical Energy Price Shocks and Their Changing Effects on the Economy; Center for Climate Change Economics and Policy: Leeds, UK, 2014.

21. Cherp, A.; Jewell, J. The concept of energy security: Beyond the four As. Energy Policy 2014, 75, 415-421. [CrossRef]

22. Schock, R.N.; Sims, R.E.H.; Torres-Martínez, J.; Adegbululgbe, A.; Fenhann, J.; Konstantinaviciute, I.; Moomaw, W.; Nimir, H.B.; Schlamadinger, B.; Turner, C.; et al. Energy Supply; Climate Change 2007-Mitigation Contribution of Working Group III to Fourth Assessment Report of the Intergovernmental Panel on Climate Change; Cambridge University Press: Cambridge, UK, 2007; p. 72.

23. Cherp, A. Energy and Security. In Global Energy Assessment-Toward a Sustainable Future; Cambridge University Press: Cambridge, UK, 2012; pp. 325-383. 
24. Reddy, A.K.N.; Annecke, W.; Blok, K.; Bloom, D.; Boardman, B.; Eberhard, A.; Ramakrishna, J.; Wodon, Q.; Zaidi, A.K. Energy and Social Issues. In World Energy Assessment: Energy and the Challenge of Sustainability; United Nations Development Programme: New York, NY, USA, 2000; pp. 40-60.

25. Edomah, N.; Foulds, C.; Jones, A. Energy transitions in Nigeria: The evolution of energy infrastructure provision (1800-2015). Energies 2016, 9, 484. [CrossRef]

26. Agu, D.O.; Ogbeide-Osaretin, E.N. An Inquiry into the Political Economy of the Global Clean Energy Transition Policies and Nigeria's Federal and State Governments' Fiscal Policies; United Nations University World Institute for Development Economics Research UNU WIDER: Helsinki, Finland, 2016.

27. Haruna, I. Nigerian-German Energy Partnership Receives a Boost: German Coy to Add 125MW Solar Power to the Grid; Nigeria Federal Ministry of Power, Works and Housing Press Public Relations: Abuja, Nigeria, 2016.

28. Edomah, N. On the Path to Sustainability: Key Issues on Nigeria's Sustainable Energy Development; Energy Reports; Elsevier: Amsterdam, The Netherlands, 2016; Volume 2, pp. 28-34.

29. United Nations. Investment Policy Review: Nigeria; United Nations Conference on Trade and Development (UNCTAD): New York, NY, USA; Geneva, Switzerland, 2009.

30. Aladeitan, L. Law and Energy Infrastructure Development in Developing Countries: A Case Study of Nigeria and Ghana; Annual Survey of International \& Comparative Law; Golden Gate University School of Law: San Francisco, CA, USA, 2014; Volume 20.

31. Melorose, J.; Perroy, R.; Careas, S. An Infrastructure Action Plan for Nigeria: Closing the Infrastructure Gap and Accelerating Economic Transformation; African Development Bank Group: Belvedere, Tunisia, 2015.

32. Bale, C.S.E.; Varga, L.; Foxon, T.J. Energy and complexity: New ways forward. Appl. Energy 2015, 138, 150-159. [CrossRef]

33. Claro, A.; Formato, T.; Huyhua, S.; Lock, R.; Martineau, K.; Moore, A.; Michaelides, P.; O’Neill, E.; Ruge, S.; Santner, A.; et al. Leveraging the Multiple Benefits of Green Infrastructure; Sustainability Management Capstone Project for New York City's Department of Environmental Protection; Columbia University: New York, NY, USA, 2013.

34. Climate and Development Knowldge Network (CDKN). The Policy Life Cycle Stages; Climate Compatible Development Tools A Guide for National Planning; CDKN: London, UK, 2015.

35. Krauss, E.S. Politics and the policymaking process. In Democracy in Japan; University of Pittsburgh Press: Pittsburgh, PA, USA, 1989; pp. 39-64.

36. Graff, C.J. Mixed methods research. In Evidence-Based Practice: An Integrative Approach to Research, Administration and Practice; Jones \& Bartlett Learning: Boston, MA, USA, 2014; pp. 45-64.

37. Archer, M.; Bhaskar, R.; Collier, A.; Lawson, T.; Norrie, A. Critical Realism: Essential Readings; Routlegde: London, UK, 1998; pp. 9-24.

38. Laforest, J.; Bouchard, L.M. Guide to Organizing Semi-Structured Interviews with Key Informant: Safety Diagnosis Tool Kit for Local Communities; Institut national de santé publique du Quebec: Quebec, QC, Canada, 2009; Volume 11, pp. 1-26.

39. Zorn, T. Designing and Conducting Semi-Structured Interviews for Research; Waikato Management School, University of Waikato: Hamilton, New Zealand, 2008; p. 11.

40. Halcomb, E.J.; Davidson, P.M. Is verbatim transcription of interview data always necessary? Appl. Nurs. Res. 2006, 19, 38-42. [CrossRef] [PubMed]

41. Mills, A.J.; Board, E.; Wiebe, E. Encyclopedia of Case Study Research: Thematic Analysis; SAGE Publishing: Thousand Oaks, CA, USA, 2010.

42. Department of Energy \& Climate Change (DECC). Overarching National Policy Statement for Energy (EN-1); Department of Energy \& Climate Change: London, UK, 2011.

43. Vann, A. Wind Energy: Offshore Permitting; Congressional Research Service (CRS) Report for Congress; CRS: Washington, DC, USA, 2012.

44. Schwartz, D.L. The Energy Regulation and Markets Review; Law Business Research Ltd.: London, UK, 2012.

45. Schultz, J.; Sharpe, O. The Role of Regulation in Australia's Future Energy Mix; Environment and Climate Change Law Library: Adelaide, Australia, 2014.

46. European Commission. The Economic Impact of Enforcement of Competition Policies on the Functioning of EU Energy Markets; European Commission Directorate-General for Competition; European Commission: Brussels, Belgium; Luxembourg City, Luxembourg, 2016. 
47. Koyama, K. Significance of Competition Policy in Energy Market_Its Bright and Dark Sides; The Institute of Energy Economics, Japan-Special Bulletin, IEEJ: Tokyo, Japan, 2013; pp. 1-3.

48. Office of Fair Trading. Assessment of Market Power; Competition Law 2004; Office of Fair Trading: Edinburg, UK, 2004.

49. Kim, S.R.; Horn, A. Regulation Policies Concerning Natural Monopolies in Developing and Transition Economies; DESA Discussion Paper; United Nations Department of Economic and Social Affairs: New York, NY, USA, 1999.

50. Biermann, F.; Abbott, K.; Andresen, S.; Backstrand, K.; Bernstein, S.; Betsill, M.M.; Bulkeley, H.; Cashore, B.; Clapp, J.; Folke, C.; et al. Transforming governance and institutions for global sustainability: Key insights from the Earth System Governance Project. Curr. Opin. Environ. Sustain. 2012, 4, 51-60. [CrossRef]

51. Mitchell, C.; Woodman, B.; Kuzemko, C.; Hoggett, R. Public Value Energy Governance: Establishing an Institutional Framework Which Better Fits a Sustainable, Secure and Affordable Energy System; EPG Working Paper; University of Exeter: Exeter, UK, 2015.

52. Cunningham, E.A. The State and the Firm: China's Energy Governance in Context; Global Economic Governance Initiative Working Paper; Boston University: Boston, MA, USA, 2015; pp. 1-44.

53. Florini, A.; Sovacool, B.K. Who governs energy? The challenges facing global energy governance. Energy Policy 2009, 37, 5239-5248. [CrossRef]

54. Beach, S.; Keast, R. Governance networks and stakeholders: Engaging through salience. In Proceedings of the Annual Conference of the International Research Society for Public Management (IRSPMXIV), Berne, Switzerland, 7-9 April 2010; pp. 1-14.

55. Giddens, A. The Consequences of Modernity; Stanford University Press: Palo Alto, CA, USA, 1991.

56. Zábojník, J. Centralized and Decentralized Decision Making in Organizations. J. Labor Econ. 2002, 20 , 1-22. [CrossRef]

57. Amundsen, I. Political Corruption: An Introduction to the Issues; Michelsen Institute of Development Studies and Human Rights: Bergen, Norway, 1999.

58. Marcel, V.; Heller, P. Governance Challenges for Emerging Oil and Gas Producers; EEDP Programme Paper; Chatham House: London, UK, 2012.

59. Sambo, A. Matching Electricity Supply with Demand in Nigeria; International Association for Energy Economics: Cleveland, OH, USA, 2008; pp. 32-36.

60. Hemme, K. Critical Infrastructure Protection: Maintenance is National Security. J. Strategy Secur. 2015, 8, 25-39. [CrossRef]

61. World Bank. Deterring Corruption and Improving Governance in the Electricity Sector; World Bank: Washington, DC, USA, 2009.

62. Ruth, M. Corruption and the Energy Sector; Management Systems International: Arlington, VA, USA, 2002.

63. Kumar, S.K. Delusion and discovery: An appraisal of chetanbhagat's five point someone. Asia Pac. J. Res. 2014, 1, 5504.

64. Buddhist Publication Society. Economic Delusion; Buddhist Publication Society Newsletter: Kandy, Sri Lanka, 2009.

65. Isaksson, A. Energy Infrastructure and Industrial Development; Research and Statistics Branch Working Paper; United Nations Industrial Development Organization: Vienna, Austria, 2009.

66. Jackel, F. The History of the Nigerian Railway: Networks and Infrastructures; Spectrum Publishers: Ibadan, Nigeria, 1997.

67. Stern, D.; Kander, A. The role of energy in the industrial revolution and modern economic growth. Energy J. 2012, 33, 125-152. [CrossRef]

(C) 2016 by the authors; licensee MDPI, Basel, Switzerland. This article is an open access article distributed under the terms and conditions of the Creative Commons Attribution (CC-BY) license (http:/ / creativecommons.org/licenses/by/4.0/). 